\title{
Treatment of pediatric pulmonary hypertension
}

This article was published in the following Dove Press journal:

Vascular Health and Risk Management

3 June 2009

Number of times this article has been viewed

\section{Amy Hawkins \\ Robert Tulloh \\ Department of Congenital Heart Disease, Bristol Royal Hospital \\ for Children, Bristol UK}

Correspondence: Robert Tulloh

Department of Congenital Heart Disease, Bristol Royal Hospital for Children, Upper Maudlin Street, Bristol BS2 8BJ, UK

Tel +44 I I 73428856

Fax +44 II73428857

Email robert.tulloh@uhbristol.nhs.uk
Abstract: Pulmonary hypertension was once thought to be a rare condition and only managed in specialized centers. Now however, with the advent of echocardiography, it is found in many clinical scenarios, in the neonate with chronic lung disease, in the acute setting in the intensive care unit, in connective tissue disease and in cardiology pre- and postoperatively. We have a better understanding of the pathological process and have a range of medication which is starting to be able to palliate this previously fatal condition. This review describes the areas that are known in this condition and those that are less familiar. The basic physiology behind pulmonary hypertension and pulmonary vascular disease is explained. The histopathologic process and the various diagnostic tools are described and are followed by the current and future therapy at our disposal.

Keywords: pulmonary hypertension, congenital heart disease, pulmonary vascular resistance, pulmonary vasodilators

\section{Introduction}

Pulmonary arterial hypertension $(\mathrm{PAH})$ can be implicated in the morbidity and mortality of many areas of cardiac and noncardiac pathology, and is an important complication in many patients with congenital heart disease. ${ }^{1-3}$ Traditionally, a diagnosis of PAH was accompanied by a bleak prognosis, with the survival with "primary" pulmonary hypertension being only 2.8 years. However, in recent years, increased awareness of this condition combined with more effective intervention at an early stage has reduced the number of patients with advanced pulmonary vascular disease (PVD), and improved survival rates. ${ }^{1}$

\section{Definition}

Pulmonary arterial hypertension can be defined as an increase in pulmonary arterial pressure (PA pressure) in the pulmonary vascular bed, ${ }^{1}$ and is defined as a mean PA pressure of more than $25 \mathrm{mmHg}$ at rest or $30 \mathrm{mmHg}$ with exercise. ${ }^{2}$ However, in clinical practice, echocardiography is often used instead of cardiac catheterization, and thus pulmonary hypertension $(\mathrm{PH})$ is more commonly considered to occur when systolic PA pressure $>$ half systolic systemic pressure. ${ }^{3}$ This allows for age-related changes since a pressure of $30 \mathrm{mmHg}$ in a $300 \mathrm{~g}$ baby has different implications to that in a $70 \mathrm{~kg}$ adult. PA pressure is formed by a combination of pulmonary blood flow and pulmonary vascular resistance, known as a modification of Ohm's law $(\mathrm{V}=\mathrm{I} \times \mathrm{R})$ or Darcy's law. ${ }^{4}$ In the fetus, the pulmonary vascular resistance (PVR) is high, which maintains a high mean PA pressure and so blood is preferentially shunted from the 
pulmonary artery to the systemic circulation via the arterial duct. Within a few days of birth, the PVR falls rapidly, leading to a consequent fall in PA pressure. ${ }^{5}$ However, if there is a disease process which falls to allow the PVR to fall or if there is a pathological increase in either pulmonary blood flow or pulmonary vascular resistance, pulmonary hypertension will be maintained or will recur at a later age.

\section{Causes of pulmonary hypertension}

As the Venice classification states, ${ }^{6}$ pulmonary hypertension can be divided into a number of causes, including pulmonary arterial hypertension, pulmonary venous hypertension, and pulmonary hypertension due to respiratory causes. This can be simplified for clinical practice in pediatrics (Table 1). ${ }^{3}$ One of the main distinctions is between primary or idiopathic pulmonary arterial hypertension (IPAH), which is extremely rare in pediatric patients, and secondary pulmonary hypertension, which constitutes the remainder of the causes. Of these secondary causes, congenital heart disease with a large left to right shunt secondary to a VSD or AVSD and chronic lung disease are the most common after the first few days of life. ${ }^{3}$

\section{Pathogenesis}

The histopathologic changes seen in PH are characterized by a process of vascular remodeling, which varies somewhat depending on the etiology. This involves proliferation of smooth muscle cells into peripheral (usually nonmuscular) arteries, ${ }^{7}$ together with medial hypertrophy in normally muscular arteries. Impaired growth and loss of arterioles leads to a reduction in arterial density, and this is eventually accompanied by dilatation complexes, plexogenic lesions and fibroid necrosis. ${ }^{8}$ In turn, this leads to a process of luminal obliteration. ${ }^{9,10}$ It is generally accepted that the early stages of this are reversible and the later stages are not.

\section{Clinical features}

Many of the symptoms of pediatric $\mathrm{PH}$ are nonspecific, and clinical features may be subtle even in advanced disease. ${ }^{11}$ At birth, children commonly have cyanosis with hepatomegaly, an active right ventricle on palpation and a loud pulmonary second sound on auscultation. ${ }^{3}$ This persistent pulmonary hypertension of the newborn (PPHN) may be difficult to treat but is well recognized in neonatal units and may improve with therapy to allow discharge home. If IPAH is left untreated, the most common presenting symptom is breathlessness, and children frequently present with poor appetite, faltering growth, lethargy, tachypnea, tachycardia, and irritability. ${ }^{11,12}$ Symptomatic severity has been connected to prognosis, reinforcing the need for early diagnosis and management. ${ }^{13}$ The child with congenital heart disease and a post-tricuspid shunt is however completely different. They may present late (especially if they have upper airway obstruction as in Down's syndrome) or may have inoperable or only partly palliated disease (such as pulmonary atresia with ventricular septal defect and aorto-pulmonary collateral arteries). Hence a systematic approach to investigation is required in order to identify those patients with $\mathrm{PH}$.

Clinically, the severity of PH is assessed according to a modification of the New York Heart Association (NYHA)/World Health Organization (WHO) classification of functional capacity (Table 2). ${ }^{14}$

Table I Causes of pulmonary hypertension in pediatrics

\begin{tabular}{ll}
\hline Neonatal & Persistent pulmonary hypertension (PPHN - idiopathic) \\
& Bronchopulmonary dysplasia \\
& Infection, eg, Streptococcus \\
& Structural disease, eg, congenital diaphragmatic hernia \\
Cardiac & Left to right shunt, eg,VSD, AVSD, PDA, AP window \\
& Transposition of the great arteries (even without VSD) \\
Acquired & Obstructive lesions, eg, TAPVC, MS, HLHS, HOCM, DCM \\
& Chronic hypoxia, eg, cystic fibrosis, high altitude \\
& Scoliosis \\
& Airway obstruction, eg, tonsillar hypertrophy, tracheal stenosis/malacia \\
Idiopathic & Vasculitic, eg, Connective tissue disease, sickle cell. \\
& Sporadic $20 \%$ genetic in origin \\
& Familial $60 \%$ genetic in origin \\
\hline
\end{tabular}

Abbreviations: ASD, atrial septal defect; VSD, ventricular septal defect;AVSD, atrioventricular septal defect; PDA, persistent ductus arteriosus; AP, aorto-pulmonary; TAPVC, total anomalous pulmonary venous connection; MS, mitral stenosis; HLHS, hypoplastic left heart syndrome; HOCM, hypertrophic obstructive cardiomyopathy; DCM, dilated cardiomyopathy. 
Table 2 Functional classification of pulmonary hypertension

Class I

Class II

Class III

Class IV
Patients with pulmonary hypertension but without resulting limitation of physical activity. Ordinary physical activity does not cause undue dyspnea or fatigue, chest pain or near syncope.

Patients with pulmonary hypertension resulting in slight limitation of physical activity. They are comfortable at rest. Ordinary physical activity causes undue dyspnea or fatigue, chest pain, or near syncope.

Patients with pulmonary hypertension resulting in marked limitation of physical activity. They are comfortable at rest. Less than ordinary activity causes undue dyspnea or fatigue, chest pain or near syncope.

Patients with pulmonary hypertension with inability to carry out any physical activity without symptoms. These patients manifest signs of right heart failure. Dyspnea and/or fatigue may even be present at rest. Discomfort is increased by any physical activity.

\section{Diagnosis and investigation}

A summary of the investigations recommended in the current British Cardiac Society (BCS) Guidelines ${ }^{15}$ is shown in Table 3.

A chest radiograph may show pulmonary oligemia, with pruning of peripheral vessels ${ }^{16}$ there may be right ventricular hypertrophy (RVH) on electrocardiogram (ECG), and a low partial pressure of oxygen $\left(\mathrm{PaO}_{2}\right)$ on arterial blood gas measurement. Echocardiography is a useful and sensitive investigation to identify possible secondary causes of $\mathrm{PAH}$ (such as ASD [rarely], VSD or cardiomyopathy), to provide a numerical assessment of the tricuspid regurgitation (TR) jet, and to assess left ventricular (LV) function. However, the results of derived formulae from echocardiography are to some extent operator-dependent. For older children, a six-minute walk test (6MWT) is a standardized method for assessing exercise tolerance in children, ${ }^{17}$ and it correlates well with the WHO functional class system.

Cardiac catheterization remains the diagnostic gold standard for PH. Current UK guidelines state that right heart catheterization is essential in the investigation of new patients with suspected $\mathrm{PH}$, and should be undertaken to

Table 3 Imaging investigations recommended for the assessment of $\mathrm{PH}$

\begin{tabular}{|c|c|}
\hline Investigation & Comments \\
\hline Chest radiography & $\begin{array}{l}\text { May show increase in cardiac chamber or PA size, hypoperfused areas of lung, and } \\
\text { parenchymal lung disease. }\end{array}$ \\
\hline ECG & May demonstrate RVH. \\
\hline Echocardiography & $\begin{array}{l}\text { Screening tool of choice for PAH. Detects cardiac disease (congenital, myocardial, valvular, } \\
\text { intra-cavity clot or tumor, pericardial effusion). Use of contrast may be helpful to identify shunts. }\end{array}$ \\
\hline Cardiac catheterization & $\begin{array}{l}\text { Gold standard to define the extent of disease. PA pressures, PVR, cardiac output and } \\
\text { oxygen saturations can be calculated accurately. Acute pulmonary vasoreactivity studies } \\
\text { may also be carried out. }\end{array}$ \\
\hline 6 minute walk test ( $6 \mathrm{MWT})$ & Provides a functional assessment of exercise capacity and degree of limitation of activity. \\
\hline Arterial blood gases, lung function tests & $\begin{array}{l}\text { May be useful, although in patients with IPAH the results of lung function tests may be } \\
\text { normal. A decline in } \mathrm{PaO}_{2} \text { is typically seen. }\end{array}$ \\
\hline Blood investigations & $\begin{array}{l}\text { Essential to exclude connective tissue diseases or pulmonary hypertension secondary } \\
\text { to systemic disease: routine biochemistry and hematology, thyroid function, autoimmune } \\
\text { screen (including anti-centromere antibody, anti-SCL70 and UI RNP, phospholipid } \\
\text { antibodies). }\end{array}$ \\
\hline CT pulmonary angiography (CTPA) & Used to look for enlargement of pulmonary arteries, filling defects and webs in the arteries. \\
\hline Ventilation perfusion scanning & $\begin{array}{l}\text { More sensitive for chronic pulmonary thromboembolism than CTPA but not helpful when } \\
\text { there is underlying parenchymal lung disease. }\end{array}$ \\
\hline High resolution lung CT & $\begin{array}{l}\text { May show parenchymal lung disease, mosaic perfusion (a sign of pulmonary vascular } \\
\text { embolism or thrombosis but for which there are other causes such as air trapping), and } \\
\text { features of pulmonary venous hypertension. }\end{array}$ \\
\hline Cardiac MRI & $\begin{array}{l}\text { Good investigation for imaging the right ventricle. Helpful in delineating congenital heart } \\
\text { defects, and the pulmonary circulation by angiography. }\end{array}$ \\
\hline Abdominal ultrasound & Used for investigation of liver disease and suspected portal hypertension. \\
\hline
\end{tabular}

Abbreviations: PA, pulmonary artery; RVH, right ventricular hypertrophy; PAH, pulmonary arterial hypertension; PVR, pulmonary vascular resistance; IPAH, idiopathic pulmonary arterial hypertension. 
assess specific and accurate measurements of PA pressure and PVR. ${ }^{15}$ Vasodilator testing with inhaled nitric oxide ${ }^{16}$ or prostacyclin ${ }^{17}$ can also be carried out at the time of catheterization to assess the degree of reversibility of PH. In recent years, magnetic resonance imaging (MRI) has enabled detailed visualization of cardiac anatomy and pulmonary blood flow, ${ }^{20}$ and may even be used to assess degree of vessel compliance. $^{21}$

\section{Control of pulmonary vascular resistance}

There are a number of different pathways involved in the control of PVR, many of which are therapeutic targets in the management of PAH, and are therefore essential to an understanding of the management of this condition (Table 4).

Patients with PAH have increased levels of circulating endothelin-1.22,23 As well as causing vasoconstriction, endothelin-1 leads to smooth muscle and fibroblast proliferation via endothelin $\mathrm{A}\left(\mathrm{ET}_{\mathrm{A}}\right)$, and/or endothelin $\mathrm{B}\left(\mathrm{ET}_{\mathrm{B}}\right)$ receptors. ${ }^{24}$ Serotonin levels are also raised in $\mathrm{PAH}$, which stimulates mitogenesis of vascular cells, and increased expression of the serotonin transporter is found in hypertensive arteries. ${ }^{25}$ Patients with severe PAH have a relative deficiency of vasodilator pathways; they produce less endogenous prostacyclin, have reduced nitrogen oxide synthase (NOS) expression, and reduced vasoactive intestinal peptide (VIP) in the lungs. ${ }^{26,27}$

\section{Prevention of pediatric pulmonary hypertension}

Despite the advent of more efficacious therapeutics, prevention of pediatric pulmonary hypertension remains a priority. Patients with congenital heart defects secondary to a left to right shunt lesion should undergo early surgery to prevent development of PVD. This is particularly crucial in those patients with an AVSD or VSD. ${ }^{28}$ Surgical and post-operative care is also crucial, and improvements in this area are likely to be a contributing factor in the declining incidence of postoperative pulmonary hypertension in children following cardiac surgery. ${ }^{29}$ This involves adequate ventilation, chest physiotherapy, and, if necessary, antibiotics.

It is also essential to maintain good oxygenation, relatively low $\mathrm{CO}_{2}$ and $\mathrm{pH}$ towards the upper limit of normal, in order to reduce the PA pressure as much as possible. Consequently, the effectiveness of pulmonary vasodilatation will also be maximized. Use of sedation with fentanyl and clonidine should also be used as prophylaxis against pulmonary hypertensive crises. ${ }^{30}$

\section{Treatment of pediatric pulmonary hypertension}

Current guidelines recommend that patients with PH should be managed by an experienced multiprofessional team at a specialist centre, with appropriate expertise and support for children and their families. Long-term community care involving clinical nurse specialists is also beneficial. ${ }^{15}$

Response to treatment is less predictable in children, and therefore, close monitoring and rapid alteration of treatment as necessary is required in pediatric patients. ${ }^{15}$ Research has suggested that prompt medical treatment of PAH, even in patients with established disease and Eisenmenger's syndrome, may reduce the need for lung transplantation. ${ }^{31}$ There are fewer therapeutic options currently available for patients with $\mathrm{PH}$ in comparison to those with PAH.

Initially, treatment of $\mathrm{PH}$ involves thorough investigation of potential underlying causes; treatment will thus be directed accordingly. For example, patients whose PAH is caused by upper airway obstruction might undergo adenotonsillectomy, and those with cystic fibrosis, asthma or bronchopulmonary dysplasia should be managed with the relevant therapeutics. Drugs with a propensity to cause vasoconstriction such

Table 4 Summary of mechanisms in PHT

\begin{tabular}{lll}
\hline Agent & Mechanism & Outcome \\
\hline $\begin{array}{l}\text { Hypoventilation } \\
\text { Nitric oxide }\end{array}$ & Not fully understood, due to hypoxia and hypercarbia & Increases guanylyl cyclase \\
Nitrates & & Vasoconstriction \\
Phosphodiesterase type V inhibitors & Prevent cyclic GMP breakdown & A - receptor \\
Endothelin & B - receptor & Vasodilation \\
Prostanoids & Increase cyclic AMP \\
Rho-Kinase inhibitors & Increase GMP effect & Vasodilation and anti-mitogenic \\
Serotonin antagonists & 5HT transporter & Vasodilation
\end{tabular}

Abbreviations: GMP, guanosine monophosphate; AMP, adenosine monophosphate. 
as sympathomimmetic decongestants with $\alpha$-adrenergic properties should be avoided in children with pulmonary hypertension.

It is important to note that UK guidelines differ from those in other parts of the world; the American College of Chest Physicians (ACCP) and the European Society of Cardiologists (ESC) suggest that those in NYHA class III or IV should be treated with a specific oral therapy. ${ }^{32,33}$

Recent guidelines have suggested a treatment algorithm for the management of pediatric $\mathrm{PAH}^{15}$ (Figure 1).

\section{Treatment of acute disease}

Children presenting with syncope, right heart failure or post-operative PAH must be diagnosed and treated promptly and safely. ${ }^{34}$ This may be in an inhaled form (see Nitric oxide, below), orally with sildenafil, intravenously (see Epoprostenol, below), or with hemodynamic support (see Extracorporeal membranous oxygenation, below). ${ }^{3}$

\section{Oxygen}

Good ventilation in the intensive care unit is essential (see Treatment of pediatric pulmonary hypertension, above), and oxygen therapy has been shown to be of benefit acutely for both hypoxic and nonhypoxic patients with PAH. ${ }^{15}$ Additionally, some patients may benefit from the use of domiciliary nocturnal oxygen therapy, both acutely, and alongside maintenance therapy. ${ }^{35}$

\section{Nitric oxide}

Nitric oxide (NO) inhalation is currently among the first line treatments for post-operative pediatric pulmonary hypertension or in the child with acute severe new presentation of $\mathrm{PAH}$ being managed on the intensive care unit, ${ }^{36,37}$ as it reduces PA pressure rapidly. ${ }^{38}$ Inhaled NO therapy is also used acutely in persistent pulmonary hypertension of the newborn. ${ }^{39}$ The mode of action of NO is via the stimulation of guanylyl cyclase and hence increased production of cyclic guanylate monophosphate (cGMP) in pulmonary smooth muscle cells; this causes uptake of calcium into the sarcoplasmic reticulum, which then leads to muscle relaxation, reduced PA pressure and PVR, and hence increased oxygenation. Any NO absorbed from the lungs into the systemic circulation is quickly deactivated by combination with hemoglobin, minimising any effect on the systemic circulation. Therefore, NO acts solely on the pulmonary vasculature, leaving systemic arterial pressure unaffected. ${ }^{40,41}$

Oxygenation index $(\mathrm{OI})$ is a calculation combining fraction of inspired oxygen $\left(\mathrm{FiO}_{2}\right)$, mean airway pressure and $\mathrm{PaO}_{2}$ as an indicator of degree of respiratory compromise; ${ }^{42}$ OI of more than 25 is the usual indication for initiation of treatment with NO. ${ }^{43}$ Acutely, doses start at 20 parts per million (ppm), ${ }^{44}$ although post-operative PAH may be treated with doses as low as 3-10 ppm. ${ }^{45}$ Sustained high doses of NO may lead to methemoglobinemia, ${ }^{45,46}$ and acute withdrawal of treatment may precipitate rebound $\mathrm{PAH} .{ }^{44}$ The latter may be avoided by the use of phosphodiesterase inhibitors (see below), prostacyclins (see below) or discontinuation of NO followed by resumption of treatment at half the dose. ${ }^{47}$ Despite this, there is no clear evidence that short-term use of NO causes significant cardiac and respiratory complications. ${ }^{48}$

NO administration has been shown to reduce the need for extracorporeal membrane oxygenation (ECMO) treatment in term or near term neonates with hypoxic respiratory failure. ${ }^{42}$ However, a recent Cochrane review found that there was no significant difference in short-term post-operative mortality or mean PA pressure with administration of inhaled NO compared to placebo or conventional management (hyperventilation, use of sodium bicarbonate, intravenous inotropes and vasodilatory agents, and sedatives). ${ }^{49}$ Current European guidance suggests that there is insufficient evidence at present to recommend the use of prophylactic post-operative inhaled NO in patients with congenital heart disease at risk of PAH. ${ }^{50}$ However, there is sufficient evidence to support a trial of NO therapy (with a starting dose of $20 \mathrm{ppm}$, increasing to $40 \mathrm{ppm}$ if there is no response) in patients with significant peri-operative $\mathrm{PAH} .{ }^{50}$ Treatment should be discontinued after 30 minutes if there has been no clinically significant response.

\section{Extracorporeal membrane oxygenation (ECMO)}

The use of extracorporeal membrane oxygenation (ECMO) has been associated with complications including interstitial and alveolar hemorrhage and secondary epithelial alterations. ${ }^{51}$ For this reason, since the establishment of inhaled NO therapy as a treatment for pediatric PAH, the use of ECMO has significantly decreased. ${ }^{52}$ Despite this, there are still some incidences in which ECMO therapy is necessary, such as those infants with severe respiratory or cardiac disease in addition to pulmonary arterial hypertension; one study of children with hypoxemic respiratory failure found that treatment with NO alone was successful in only $29 \%$ cases. $^{53}$

\section{Maintenance therapies}

Aims of maintenance therapies for pediatric pulmonary hypertension will generally be to lower PA pressure in order to reduce or reverse the rate of progression of PVD, and thus to obtain functional improvement in terms of increased activity levels. 


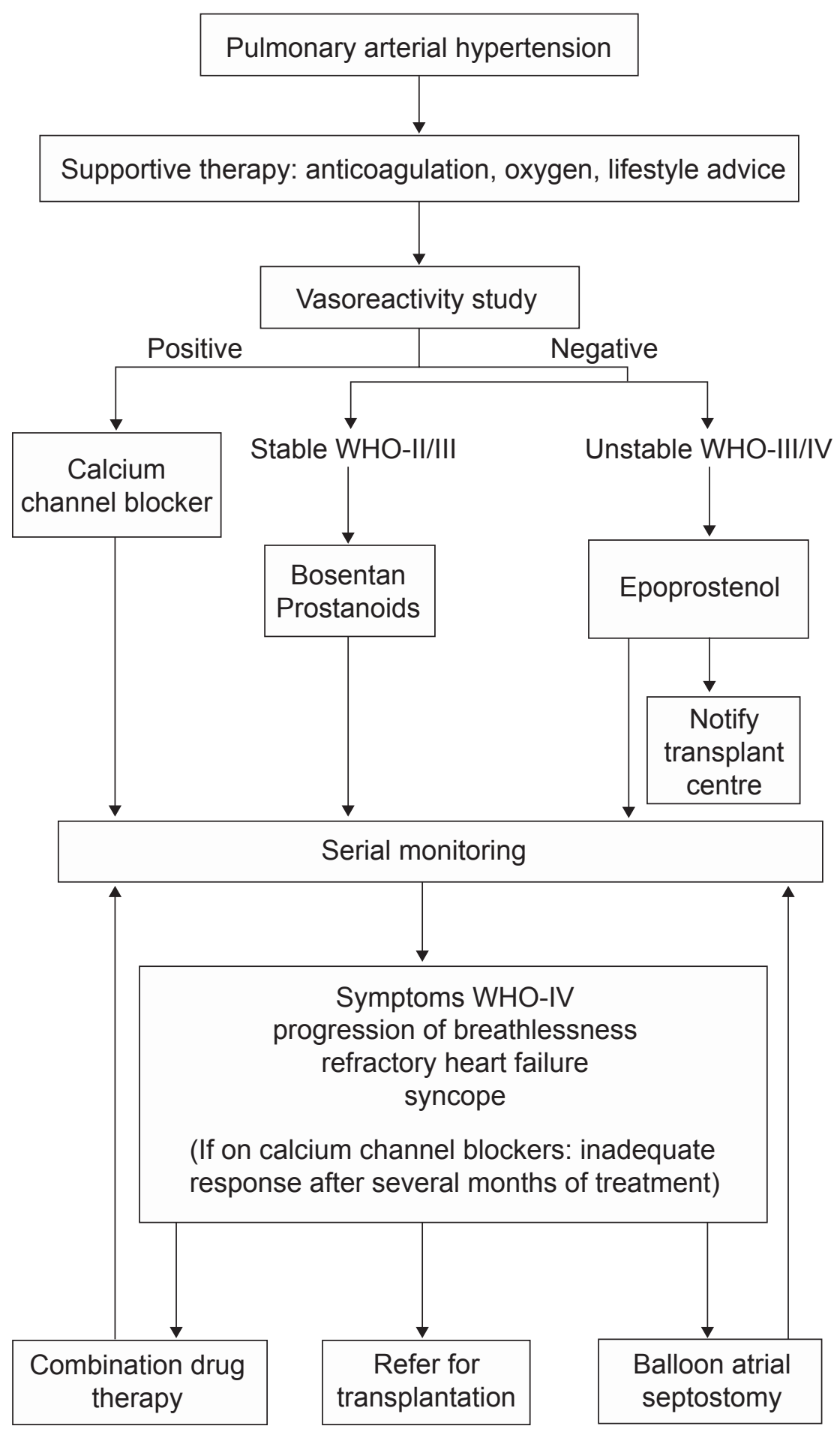

Figure I Current British Cardiovascular Society (BCS) algorithm for the management of PAH in children. Abbreviation: WHO, World Health Organization.

Current guidelines state that the choice of therapy should be based on WHO functional class and response to vasodilator testing during cardiac catheterization. ${ }^{15}$ The age of the child is also an important factor, as several drugs used to treat adults are unsuitable for use in young children; subcutaneous treprostinil frequently causes significant pain, and unwell children may be unable to tolerate inhaled doses of iloprost every 2-3 hours..$^{15}$

In the UK, current statistics suggest that only a minority of patients are responsive to vasoreactivity studies and 
treatment with calcium channel antagonists (see below). ${ }^{15}$ Therefore, the majority of children are treated with specific disease-targeted therapies, such as intravenous epoprostenol (the only drug for children tested in a placebo-controlled trial), ${ }^{54}$ bosentan, ${ }^{55}$ and sildenafil. Choice of drug is dependent upon a number of factors, including side effect profile, route of administration, patient preferences, and physician experience. $^{33}$

\section{Calcium channel antagonists}

The calcium channel antagonist, nifedipine is one of the oldest agents used for $\mathrm{PAH},{ }^{56,57}$ and amlodipine has been suggested to be beneficial for IPAH. ${ }^{58}$ An initial trial of these agents should be carried out, and calcium channel antagonists should only be continued in those patients who demonstrate an adequate vasodilator response (defined by a decrease in mean PA pressure and PVR by $>20 \%) .{ }^{59}$ These patients may need no further medication. ${ }^{56,58}$ However, calcium channel antagonists are only efficacious in 5\%-10\% of children and adults, whereas nonresponders demonstrate a continually rising PVR. Some patients may switch from being 'responders', demonstrating a stable response to calcium channel blockers for a period of several years, to 'nonresponders,' who suddenly require additional medication.

\section{Phosphodiesterase inhibitors}

Sildenafil, a phosphodiesterase inhibitor, given orally, has been shown to be a potent and selective pulmonary vasodilator. ${ }^{60}$ Sildenafil works by selectively inhibiting phosphodiesterase V (PDE V), ${ }^{61}$ which is responsible for cGMP breakdown in lung tissue. The resultant increase in cGMP leads to calcium-mediated relaxation of vascular smooth muscle. These effects on pulmonary vasculature appear to occur independently of the cause of $\mathrm{PAH}$, suggesting a role in the management of IPAH. ${ }^{62}$

An initial small-scale pilot study suggested that sildenafil improves hemodynamics and exercise capacity in children with primary pulmonary hypertension and $\mathrm{PAH}$ secondary to congenital heart disease ${ }^{63}$ Since then, research has suggested that sildenafil works by improving endothelial-dependent vasodilatation, and by reducing plasma concentrations of endothelin-1 and von Willebrand factor, mediating a fall in PA pressure and PVR. ${ }^{64}$ In IPAH and Eisenmenger's syndrome, there are reduced levels of endothelial progenitor cells; sildenafil has been hypothesized to increase numbers of these cells in the long term, thereby reducing endothelial dysfunction. ${ }^{65}$ Another study found that patients with $\mathrm{PAH}$ secondary to congenital heart defects treated with sildenafil had improved exercise capacity, WHO functional class and hemodynamics. ${ }^{6}$ Similarly, Baharani and colleagues found that patients with CHD had significant improvements in six-minute walking distance (6-MWD) and systolic PA pressure when treated with sildenafil in comparison with placebo. ${ }^{67}$ Sildenafil has been suggested to improve mean PA pressure, PVR, and exercise tolerance in PAH. ${ }^{68}$ Research has suggested that there is a direct dose-response relationship between sildenafil and exercise capacity, measured by 6-MWD; one study observed a significant improvement in 6-MWD in patients taking $50 \mathrm{mg}$ sildenafil three times daily (tds) compared to $25 \mathrm{mg}$ tds or $12.5 \mathrm{mg}$ tds. ${ }^{69}$

Sildenafil has also been shown to work synergistically with NO, enhancing the efficacy of exogenous NO, which further increases vasodilatation..$^{70}$ This combined approach enables transfer of patients from intensive care, and facilitates weaning from high doses of nitric oxide, by reducing the rebound effect commonly seen with discontinuation of inhaled NO. ${ }^{18,71}$ In the long-term, sildenafil demonstrates marked down-regulatory responses which may limit its use, ${ }^{67}$ although this may be lessened when administered alongside NO. Side-effects of sildenafil may include nausea, abdominal discomfort, headache, dizziness and flushing ${ }^{72}$ and potentially, in the long-term, memory loss. ${ }^{73}$

More recently, research has suggested that another PDE type 5 inhibitor, vardenafil, may be more effective than sildenafil in vitro. ${ }^{74,75}$ These studies have suggested that vardenafil acts directly to reduce calcium influx in the pulmonary artery, in addition to its vasodilatory effects via cGMP.

\section{Endothelin receptor antagonists}

Endothelin $1(\mathrm{ET}-1)$ acts on $\mathrm{ET}_{\mathrm{A}}$ and $\mathrm{ET}_{\mathrm{B}}$ receptors to promote mitosis of pulmonary artery smooth muscle cells; activation of $\mathrm{ET}_{\mathrm{A}}$ and $\mathrm{ET}_{\mathrm{B}}$ on smooth muscle cells causes vasoconstriction, whereas activation of $\mathrm{ET}_{\mathrm{B}}$ on the endothelial cell releasing NO causes vasodilatation. This is thought to contribute significantly to the imbalance between vasodilatation and vasoconstriction in pulmonary hypertension ${ }^{76}$ and high levels of ET-1 have been found in the lung and circulation of patients with PAH. ${ }^{77,78}$

Bosentan, a nonselective (endothelin receptor A and B) antagonist has been shown to reduce mean PA pressure and PVR, and increase quality of life in patients with IPAH. ${ }^{17}$ One study found that in pediatric patients with congenital heart disease or connective tissue disease, treatment with bosentan for a median period of 14 months improved WHO functional class in $46 \% .{ }^{79}$ Bosentan has also been found to be effective in patients with Eisenmenger's syndrome, reducing PA pressure 
and PVR and improving exercise capacity, without reducing oxygen saturations (the BREATHE-5 trial). ${ }^{80,81}$ However, bosentan has been shown to cause hepatic dysfunction in some patients; a recent study identified deranged liver function tests in $2.7 \%$ of children under 12 years of age on bosentan therapy, compared to $7.8 \%$ of those aged over 12 years. $^{82}$ There is some evidence to suggest that in the long-term, there is a progressive decline in the beneficial treatment effects of bosentan, particularly in children. ${ }^{83}$

Sitaxsentan, a more $\mathrm{ET}_{\mathrm{A}}$ selective ERA has been investigated in recent trials. Research has suggested that that it may play an important role in the management of PAH associated with connective tissue diseases, and it may have a more prolonged action than bosentan in children with congenital heart disease.$^{84,85}$ One study of 247 patients found that use of sitaxsentan $100 \mathrm{mg}$ once daily improved exercise capacity and WHO functional class in adult patients with PAH, and it has reduced hepatic toxicity compared to bosentan. ${ }^{86}$ As well as bosentan, sitaxsentan has also been shown to be effective in patients with Eisenmenger's syndrome. ${ }^{87}$ Data on the use of sitaxsentan is limited in children at the current time.

Ambrisentan, another selective ERA antagonist has recently been shown to improve exercise capacity in patients with PAH compared to placebo, and is well-tolerated. ${ }^{88}$

\section{Prostacyclin agonists}

Prostacyclin $\left(\mathrm{PGI}_{2}\right)$ is an endogenous vasodilatory mediator in the pulmonary vasculature; prostacyclin agonists act via cyclic AMP-dependent pathways in smooth muscle cells. Its effects include reducing PVR, inhibiting platelet aggregation, and reducing smooth muscle cell proliferation. In patients with pulmonary hypertension, pulmonary endothelial cells have decreased expression of prostacyclin synthase ${ }^{89}$ and urinalysis demonstrates a decrease in stable prostacyclin metabolites. ${ }^{26}$

Preliminary results of treatment with prostacyclins have been promising. Barst and colleagues ${ }^{90}$ found a $90 \%$ survival rate at four years for children with severe IPAH treated with prostacyclin, and studies have suggested that prostacyclins improve hemodynamic function and quality of life. ${ }^{91}$ Prostacyclins have been shown to work synergistically with NO, since they act through a different pathway and hence the therapeutic effects are additive. Therefore, these drugs may also be used when NO treatment has failed, when weaning from NO (as also occurs with sildenafil), or when therapeutic resistance has occurred. ${ }^{47,92}$ They may be administered intravenously (epoprostenol, treprostinil), by inhalation (iloprost) or orally (beraprost). However, the side-effects of prostacyclin agonists have limited their use to some extent; adverse events associated with epoprostenol include flushing, jaw pain, headaches, rashes and thrombocytopenia. ${ }^{93}$ Epoprostenol requires a continuous infusion and has a short half-life ( $<6$ minutes). Interruption of the infusion can lead to rapid increases in PVR, hemodynamic collapse and death. ${ }^{93}$

Epoprostenol has been shown to improve the survival of patients with IPAH in the long-term, ${ }^{94}$ and is the gold standard starting treatment for patients with severe IPAH. It also has a role acutely in neonates with persistent pulmonary hypertension of the newborn (PPHN), post-operatively in children with heart disease, and in patients with IPAH, to reduce PVR prior to cardiac catheterization. However, epoprostenol has dose-limiting effects, and may cause severe rebound pulmonary arterial hypertension..$^{95}$

Treprostinil was originally used as a subcutaneous infusion, which has a longer half-life and increased stability, so does not have to be kept in cooled storage. ${ }^{96}$ However, this route of administration is extremely painful, which has limited its use in the pediatric population. In recent research, intravenous preparations of treprostinil have been investigated, which have been suggested to cause fewer adverse effects than epoprostenol. However, whilst successful transfer rates have been achieved, high central-line infection rates were seen. ${ }^{97}$

Beraprost, an oral preparation, is well-tolerated and widely used in parts of Europe and in Japan, but research has suggested it is less efficacious than intravenous preparations. $^{98,99}$

The inhaled form, iloprost, is easy to administer, has fewer side-effects as it acts directly on the lungs ${ }^{100}$ and it avoids the potential risks of infection seen with indwelling central lines. ${ }^{95}$ Iloprost must be administered approximately every two hours, and therefore has a greater role in the acute setting. It has been shown to be effective in improving hemodynamic parameters, exercise tolerance and quality of life in patients with PAH. ${ }^{101,102}$

\section{Novel therapies}

\section{Rho-kinase inhibitors}

Developments in recent years have suggested that a new class of drug, rho kinase inhibitors, may be beneficial in the treatment of pediatric PAH. ${ }^{103,104}$ Rho kinase causes vasoconstriction of vascular smooth muscle through phosphorylation and consequent inhibition of myosin phosphatase. ${ }^{105}$ It has also been shown that rho kinase acts by activation of the enzyme myosin light chain kinase (MLCK), which causes 
phosphorylation of the hyper-constrictive segments of arteries in vitro. ${ }^{106}$ Animal models have suggested that activation of rho kinase is associated with pulmonary vasoconstriction and proliferation, impaired endothelial vasodilatation and pulmonary remodelling, and that administration of its antagonists reverse these processes. ${ }^{107,108}$ Preliminary results have suggested that administration of intravenous fasudil, a selective rho-kinase inhibitor, may cause acute pulmonary vasodilatation and reduction in PA pressure in patients with severe PAH refractory to other therapies. ${ }^{103,109}$

\section{Vasoactive intestinal peptide}

Recent research investigating the role of vasoactive intestinal peptide (VIP) in rats has produced promising results. ${ }^{110}$ This study showed that $\mathrm{ET}_{\mathrm{A}}$ antagonists, $\mathrm{ET}_{\mathrm{B}}$ antagonists, and VIP all prevented the pulmonary vasoconstriction caused by ET1. Unlike $\mathrm{ET}_{\mathrm{A}}$ and $\mathrm{ET}_{\mathrm{B}}$ antagonists, VIP did not induce an increase in airway resistance and thus this peptide may exert protective effects against both the vascular and bronchial adverse effects of ETI. This may therefore have a role in patients with $\mathrm{PAH}$ and co-existing chronic lung disease. Clearly therefore, in vivo experimentation is now needed.

\section{Estradiol derivatives}

There has been limited investigation into the use of 2-ethoxyestradiol, a nonestrogenic metabolite of estradiol in the treatment of PAH. ${ }^{111}$ This study found that 2-ethoxyestradiol lowered right ventricle (RV) peak systolic pressure and consequently led to reduced vascular remodelling and mortality in rats with PAH. This suggests that in vitro anti-proliferative agents including synthetic analogues of estradiol metabolites may be protective against development of PVD.

\section{Apoptosis and gene therapy}

Limited research has suggested that modulation of the process of apoptosis (programmed cell death) involved in the process of vascular remodelling in PAH could be one possible therapeutic opportunity. ${ }^{12,113}$ For example, survivin (also known as Birc5), is one of a family of genes known to inhibit apoptosis; the use of molecular antagonists of survivin to increase cell death and prevent vascular remodelling may, in the future, hold therapeutic potential. ${ }^{114}$ Similarly, preliminary research has suggested that the use of the 3-hydroxy-3-methyl-glutaryl-CoA (HMG CoA) reductase inhibitor, pravastatin, and the Cox-2 inhibitor, celecoxib, prevent the development of monocrotaline-induced $\mathrm{PAH}$ in rats. ${ }^{115,116}$ Simvastatin has been found to be ineffective in this respect in vitro. ${ }^{117}$

\section{Serotonin pathways}

Research has found that patients with PAH have increased plasma serotonin levels, ${ }^{118}$ and that over-expression of the serotonin transporter gene (SERT) increases PA pressure. ${ }^{119}$ Hypoxia and monocrotaline-induced PAH in animals has been shown to be inhibited by the selective serotonin reuptake inhibitor (SSRI), fluoxetine. ${ }^{120,121}$ So far however, studies in humans have not produced statistically significant results. ${ }^{122}$

\section{L-Arginine}

An alternative approach to inhaled NO therapy is to increase endogenous NO synthesis. Plasma L-arginine is a substrate for endothelial nitrogen oxide synthase, ${ }^{123}$ and experimental ${ }^{124}$ and clinical ${ }^{125}$ data have suggested that patients with a left-to-right shunt lesion may be deficient in L-arginine, both pre- and post-operatively. However, research has suggested that low levels of plasma arginine do not correlate with the degree of post-operative $\mathrm{PAH}^{126}$. Further trials are needed to ascertain whether peri-operative therapy with L-arginine may be beneficial.

\section{Anticoagulation}

Whilst most children with PAH will not be treated with anticoagulation, it is recommended that those at high risk of thromboembolism (such as patients with IPAH and reduced cardiac output, indwelling venoatrial shunt or severe polycythemia), should be prescribed warfarin. ${ }^{127}$

\section{Other therapies}

Although rare, children with systemic sclerosis and coexisting pulmonary hypertension should be treated with corticosteroids, which appear to slow disease progression in this group. ${ }^{128}$

\section{Combination treatment}

Currently, there is some debate as to the optimal management of patients who demonstrate clinical deterioration despite maximal targeted therapy with one agent. The use of combination therapies has been widely adopted across the US and Europe, but currently, there is little clear consensus as to the most effective and safe combinations. ${ }^{129}$ In Switzerland and other countries, combination therapies involving two or three of bosentan, iloprost, and sildenafil are commonly used but their relative merits are not yet clarified. ${ }^{130}$

Combination of sildenafil with an endothelin receptor antagonist (notably bosentan) has been recently validated in several trials, improving hemodynamic variables, exercise capacity, and quality of life in patients with IPAH 
or PAH unresponsive to monotherapy. ${ }^{131-133}$ Limited trials of treatment with bosentan and a prostacyclin agonist such as epoprostenol or iloprost have suggested this may be an effective combination. ${ }^{134,135}$ Inhaled prostacyclin and milrinone have also been postulated to work synergistically to reduce PVR. ${ }^{136}$

However, the pharmacokinetics involved are complex; at steady state, when used in combination, bosentan reduces the maximum plasma concentration of sildenafil, and sildenafil increases the concentration of bosentan. ${ }^{137}$ Further research is therefore needed to establish the clinical applications for these complex drug interactions. It is also important to note that dual treatments combine the adverse effects of both drugs, and thus the incidence of side-effects may be increased. ${ }^{138}$

\section{Management of refractory pulmonary hypertension}

Those patients who remain symptomatic despite medical therapies may require more invasive forms of management.

\section{Atrial septostomy}

Children with $\mathrm{PAH}$ and without adequate right to left shunting across the atria commonly develop recurrent syncopal episodes. ${ }^{12}$ Atrial septostomy, either by cardiac catheterization or surgically, has been shown to be beneficial in patients experiencing recurrent syncope, by creating a left to right shunt and consequently maintaining cardiac output. ${ }^{139}$ In turn, this procedure has been suggested to reduce the signs and symptoms of right heart failure. ${ }^{141-144}$ Improved survival rates have also been demonstrated following atrial septostomy; Kerstein and colleagues ${ }^{139}$ demonstrated increased survival at one and two years, $87 \%$ and $76 \%$, respectively.

\section{Lung transplantation}

Lung transplantation is currently only considered as a last resort, ${ }^{145}$ in part due to concerns regarding long-term survival rates; one study found that survival rates were $77 \%$ at one year, $62 \%$ at two years, and $55 \%$ after five years. ${ }^{146}$ Since 1986 , over 1055 children have undergone transplantation worldwide. ${ }^{147}$ Between January 1990 and June 2006, there were 977

Table 5 Key trials of pharmacological agents for the management of pediatric PAH

\begin{tabular}{|c|c|c|c|c|c|c|}
\hline First Author/year & $\begin{array}{l}\text { Official } \\
\text { acronym }\end{array}$ & $\begin{array}{l}\text { Number } \\
\text { of patients }\end{array}$ & Active drug & Comparator & $\begin{array}{l}\text { Study period } \\
\text { (weeks) }\end{array}$ & $\begin{array}{l}\text { Outcome* (active drug } \\
\text { versus comparator) }\end{array}$ \\
\hline Rubin et al $1990^{150}$ & - & 23 & Epoprostenol & Randomized controls & 8 & Net benefit \\
\hline Barst et al 1996 151 & - & 81 & Epoprostenol & Randomized controls & 12 & Net benefit \\
\hline Badesch et al $2000^{152}$ & - & 111 & Epoprostenol & Randomized controls & 12 & Net benefit \\
\hline Channick et al $200 I^{153}$ & - & 32 & Bosentan & Placebo & 12 & Net benefit \\
\hline Langleben et al $2002^{154}$ & - & 71 & Terbogrel & Placebo & 12 & Net harm \\
\hline Simonneau et al $2002^{96}$ & - & 470 & Treprostinil & Placebo & 12 & No difference \\
\hline Galie et al $2002^{155}$ & ALPHABET & 130 & Beraprost & Placebo & 12 & No difference \\
\hline Olschewski et al $2002^{101}$ & AIR & 203 & lloprost & Placebo & 12 & Net benefit \\
\hline Rubin et al $2002^{156}$ & BREATHE-I & 213 & Bosentan & Placebo & 16 & Net benefit \\
\hline Barst et al $2003^{99}$ & - & 116 & Beraprost & Placebo & 36 & Net benefit \\
\hline Sastry et al $2004^{157}$ & - & 22 & Sildenafil & Placebo & 12 & Net benefit \\
\hline Humbert et al $2004^{158}$ & BREATHE-2 & 33 & Epoprostenol + bosentan & Epoprostenol + placebo & 16 & Net benefit \\
\hline Barst et al $2004^{159}$ & STRIDE-I & 178 & Sitaxsentan & Placebo & 12 & Net harm \\
\hline Galie et al $2005^{160}$ & SUPER-I & 278 & Sildenafil & Placebo & 12 & No difference \\
\hline Wilkins et al $2005^{161}$ & SERAPH & 26 & Bosentan & Sildenafil & 16 & Net benefit \\
\hline Singh et al $2006^{162}$ & - & 20 & Sildenafil & Placebo & 8 & Net benefit \\
\hline Galie et al $2006^{80}$ & BREATHE-5 & 20 & Sildenafil & Placebo & 8 & Net benefit \\
\hline Barst et al 2006 163 & STRIDE-2 & 185 & Sitaxsentan & Placebo & 18 & Net benefit \\
\hline McLaughlin et al $2006^{164}$ & STEP & 67 & Inhaled iloprost & Placebo & 12 & Net benefit \\
\hline Hoeper et al 2006 165 & COMBI & 40 & Inhaled iloprost & Placebo & 12 & Net benefit \\
\hline Galie et al $2008^{88}$ & ARIES & 394 & Ambrisentan & Placebo & 12 & No difference \\
\hline Galie et al $2008^{148}$ & EARLY & 185 & Bosentan & Placebo & 12 & Net benefit \\
\hline Simonneau et al $2008^{138}$ & PACES & 267 & Sildenafil & Placebo & 16 & Net benefit \\
\hline
\end{tabular}

Notes: *The outcome variables are risk of death or hospitalization due to complications of $\mathrm{PH}$.

Abbreviations: $\mathrm{PAH}$, pulmonary arterial hypertension; $\mathrm{PH}$, pulmonary hypertension. 
pediatric lung transplantation; of these, the primary indication in 104 patients (10.6\%) was IPAH, 34 (3.5\%) due to CHD, 18 for PVD (1.8\%), and 17 (1.7\%) for Eisenmenger's syndrome. ${ }^{147}$ However, the use of lung transplantations is restricted by waiting times, risks of surgery, and the problems accompanying transplant rejection, and thus cannot be considered as a viable treatment option earlier in the course of disease.

\section{Treatment outcomes and prognosis}

Currently, there is no PAH-specific quality of life measure, although recent studies of outcomes in pediatric patients suggest that although physical activity is limited to approximately $50 \%$ of normal, psychological scores are $80 \%-90 \%$ of normal. ${ }^{147,148}$ These scores do not correlate with age, time since diagnosis, PVR or cause of PAH.

Treatment with disease-targeted therapies for secondary and idiopathic PAH has been shown to improve survival in a number of studies; ${ }^{15,129}$ a number of recent trials have investigated the relative efficacy of management options in pulmonary arterial hypertension (Table 5). ${ }^{149}$
A recent meta-analysis of trials of modern treatment modalities including phosphodiesterase inhibitors, endothelin receptor antagonists and prostacyclin agonists found that overall, active treatment resulted in reduction in mortality of $43 \%$ (risk ratio $0.57,95 \%$ confidence interval [CI] $0.35-0.92$; $\mathrm{p}=0.023$ ) (Figure 2). ${ }^{149}$

Survival rates are typically higher in those with secondary PAH compared to IPAH, and for those with IPAH, combination therapy is more effective than monotherapy. ${ }^{141,166}$ Children with postoperative PAH have previously had particularly poor outcomes, and therefore early detection in these patients is crucial. ${ }^{15}$ There is currently limited evidence regarding the optimal management of patients with pulmonary venous hypertension, and for patients with other forms of pulmonary hypertension.

\section{Conclusion}

Advances in available therapeutics for pulmonary hypertension have improved survival in pediatric patients. General supportive care, early diagnosis and prompt surgery for patients with PAH secondary to CHD is crucial.

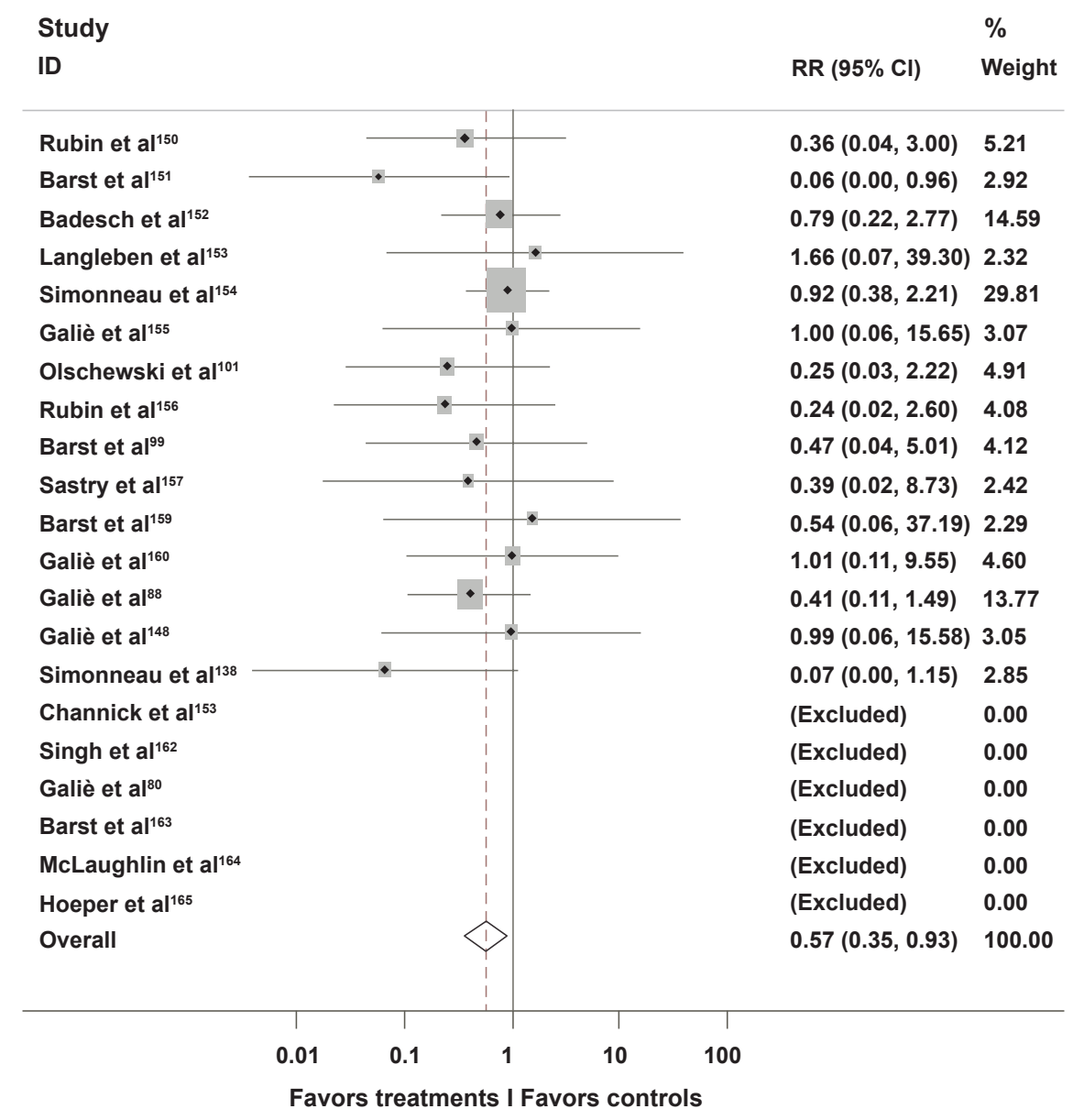

Figure 2 Meta-analysis of active treatment versus placebo in trials of current management strategies in pulmonary arterial hypertension. 
An individualized approach must be taken in deciding treatment options, depending on the symptoms, clinical signs, and hemodynamic status of each patient.

Following this, treatment options are complex and current BCS guidelines suggest that treatment should universally depend upon the NYHA functional class and response to vasodilator therapy. ${ }^{15}$ Acutely, treatment options include oxygen therapy, NO and ECMO. Current maintenance therapies include calcium channel antagonists, phosphodiesterase inhibitors, endothelin receptor antagonists and prostacyclin agonists, with or without anticoagulation. For patients who remain symptomatic or whom demonstrate equivocal hemodynamic response to therapy with a single agent, combination therapy may be considered. Atrial septostomy and lung transplantation are generally considered as the next stage in patients who have been unresponsive to medical therapy. A recent systematic review of oral treatment methods in PAH highlighted the problems of small sample size and limited follow-up period in many of the available studies this is particularly problematic in pediatric populations. ${ }^{167}$ More in vivo research is needed to assess the efficacy of the increasing number of novel therapies.

\section{Disclosure}

Dr. Hawkins reports no conflict of interest in this work. Dr. Tulloh has received lecture fees and honoria from Actelion, Pfizer and GlaxoSmithkline.

\section{References}

1. Andrews R, Tulloh R. Pulmonary hypertension in pediatrics. Curr Opin Ped. 2002;14:603-605.

2. Gibbs J. Recommendations on the management of pulmonary hypertension in clinical practice. Heart. 2001;86(Suppl 1):1-13.

3. Tulloh R. Congenital heart disease in relation to pulmonary hypertension in paediatric practice. Paediatr Respir Rev. 2005;6:174-180.

4. Freed MD. Invasive diagnostic and therapeutic techniques. Part 1: cardiac catheterisation. In Adams FH, Emmanouilides GC, Riemenschneider TA, editors. Heart Disease in Infants, Children and Adolescents. London: Williams and Wilkins; 2000. p. 130-146.

5. Andrews R, Tulloh R. Atrial septal defect with failure to thrive in infancy: hidden pulmonary vascular disease? Pediatr Cardiol. 2002;23:528-530.

6. Simonneau G, Galie N, Rubin LJ, et al. Clinical classification of pulmonary hypertension. J Am Coll Cardiol. 2004;43(12 Suppl S):5S-12S.

7. Rabinovich M. Pathobiology of pulmonary hypertension. Annu Rev Pathol. 2007;2:369-399.

8. Rabinovitch M, Keane JF, Norwood WI, Castaneda AR, Reid L. Vascular structure in lung tissue obtained at biopsy correlated with pulmonary hemodynamic findings after repair of congenital heart defects. Circulation. 1984;69:655-667.

9. Pietra GG, Edwards WD, Kay JM, Rich S, Kernis J, Schloo B et al. Histopathology of primary pulmonary hypertension. A qualitative and quantitative study of pulmonary blood vessels from 58 patients in the National Heart, Lung, and Blood Institute, Primary Pulmonary Hypertension Registry. Circulation. 1989;80:1198-1206.

10. Jeffery TK, Morrell NW. Molecular and cellular basis of pulmonary vascular remodelling in pulmonary hypertension. Prog Cardiovasc Dis. 2002;45:173-202.
11. Rich S, Dantzker DR, Ayres SM, Bergofsky EH, Brundage BH, Detre KM, et al. Primary pulmonary hypertension. A national prospective study. Ann Intern Med. 1987;107:216-223.

12. Widlitz A, Barst R. Pulmonary arterial hypertension in children. Eur Respir J. 2003;21:155-176.

13. D'Alonzo GE, Barst RJ, Ayres SM, et al. Survival in patients with primary pulmonary hypertension. Results from a national prospective registry. Ann Intern Med. 1991;115:343-349.

14. Rich S. Clinical insights into the pathogenesis of primary pulmonary hypertension. Chest. 1998;114(3 Suppl):237S-241S.

15. National Pulmonary Hypertension Centres of the UK and Ireland. Consensus statement on the management of pulmonary hypertension in clinical practice in the UK and Ireland. Thorax. 2008;63:ii1-ii41.

16. Manes A, Campana C. Pulmonary hypertension: classification and diagnostic algorithm. Ital Heart J. 2005;6:834-839.

17. Maiya S, Hislop AA, Flynn Y, Haworth SG. Response to bosentan in children with pulmonary hypertension. Heart. 2006;92:664-670.

18. Atz AM, Adatia I, Lock JE, Wessel DL. Combined effects of nitric oxide and oxygen during acute pulmonary vasodilator testing. $\mathrm{J} \mathrm{Am}$ Coll Cardiol. 1999;33:813-819.

19. Mikhail G, Gibbs J, Richardson M, Wright G, Khaghani A, Banner N. An evaluation of nebulized prostacyclin in patients with primary and secondary pulmonary hypertension. Eur Heart J. 1997;18(9): 1499-1504.

20. Muthurangu V, Taylor A, Andriantsimiavona R, Hegde S, Miquel ME, Tulloh R. Novel method of quantifying pulmonary vascular resistance by use of simultaneous invasive pressure monitoring and phase-contrast magnetic resonance flow. Circulation. 2004;110(7):826-834.

21. Muthurangu V, Atkinson D, Sermesant M, Miquel ME, Hegde S, Johnson R. Measurement of total pulmonary arterial compliance using invasive pressure monitoring and MR flow quantification during MR-guided cardiac catheterization. Am J Physiol Heart Circ Physiol. 2005;289(3):H1301-H1306.

22. Hoeper MM, Markevych I, Spiekerkoetter E, Welte T, Niedermeyer J. Goal-oriented treatment and combination therapy for pulmonary arterial hypertension. Eur Respir J. 2005;26:858-863.

23. Langleben D, DeMarchie M, Laporta D, Spanier AH, Schlesinger RD, Stewart DJ. Endothelin-1 in acute lung injury and the adult respiratory distress syndrome. Am Rev Respir Dis. 1993;148(6 Pt 1):1646-1650.

24. Davie N, Haleen SJ, Upton PD, Polak JM, Yacoub MH, Morrell NW. $\mathrm{ET}(\mathrm{A})$ and ET(B) receptors modulate the proliferation of human pulmonary artery smooth muscle cells. Am J Respir Crit Care Med. 2002;165(3):398-405.

25. Hervé P, Launay JM, Scrobohaci ML, Brenot F, Simonneau G, Petitpretz P. Increased plasma serotonin in primary pulmonary hypertension. Am J Med. 1995;99(3):249-254.

26. Christman BW, McPherson CD, Newman JH, King GA, Bernard GR, Groves BM. An imbalance between the excretion of thromboxane and prostacyclin metabolites in pulmonary hypertension. $N$ Engl $\mathrm{J} \mathrm{Med}$. 1992;327(2):70-75

27. Petkov V, Mosgoeller W, Ziesche R, Raderer M, Stiebellehner L, Vonbank K. Vasoactive intestinal peptide as a new drug for treatment of primary pulmonary hypertension. J Clin Invest. 2003;111(9): 1339-1346.

28. Bando K, Turrentine MW, Sharp TG, Sekine Y, Aufiero TX, Sun K. Pulmonary hypertension after operations for congenital heart disease: analysis of risk factors and management. J Thorac Cardiovasc Surg. 1996;112(6):1600-1607; discussion 1607-1609.

29. Lindberg L, Olsson AK, Jögi P, Jonmarker C. How common is severe pulmonary hypertension after pediatric cardiac surgery? J Thorac Cardiovasc Surg. 2002;123(6):1155-1163.

30. Ohsumi H, Sakamoto M, Yamazaki T, Okumura F. Effects of fentanyl on carotid sinus baroreflex control of circulation in rabbits. Am J Physiol. 1989;256(3 Pt 2):R625-R631.

31. Adriaenssens T, Delcroix M, Van Deyk K, Budts W. Advanced therapy may delay the need for transplantation in patients with the Eisenmenger syndrome. Eur Heart J. 2006;27(12):1472-1477. 
32. Badesch DB, Abman SH, Simonneau G, Rubin LJ, McLaughlin VV. Medical therapy for pulmonary arterial hypertension: updated ACCP evidence-based clinical practice guidelines. Chest. 2007;131(6):1917-1928.

33. Galiè N, Torbicki A, Barst R, Dartevelle P, Haworth S, Higenbottam T, et al. Guidelines on diagnosis and treatment of pulmonary arterial hypertension. The Task Force on Diagnosis and Treatment of Pulmonary Arterial Hypertension of the European Society of Cardiology. Eur Heart J. 2004;25(24):2243-2278.

34. Taylor CJ, Derrick G, McEwan A, Haworth SG, Sury MR. Risk of cardiac catheterization under anaesthesia in children with pulmonary hypertension. Br J Anaesth. 2007;98(5):657-661.

35. Sandoval J, Aguirre JS, Pulido T, Martinez-Guerra ML, Santos E, Alvarado P. Nocturnal oxygen therapy in patients with the Eisenmenger syndrome. Am J Respir Crit Care Med. 2001;164(9):1682-1687.

36. Steudel W, Hurford WE, Zapol WM. Inhaled nitric oxide: basic biology and clinical applications. Anesthesiology. 1999;91(4):1090-1121.

37. Adatia I, Barrow SE, Stratton PD, Ritter JM, Haworth SG. Effect of intracardiac repair on biosynthesis of thromboxane A2 and prostacyclin in children with a left to right shunt. Br Heart J. 1994;72(5):452-456.

38. Beghetti M, Habre W, Friedli B, Berner M. Continuous low dose inhaled nitric oxide for treatment of severe pulmonary hypertension after cardiac surgery in paediatric patients. Br Heart J. 1995;73(1):65-68.

39. Davidson D, Barefield ES, Kattwinkel J, Dudell G, Damsak K, Straube R. Inhaled nitric oxide for the early treatment of persistent pulmonary hypertension of the term newborn: a randomized, doublemasked, placebo-controlled, dose-response, multicenter study. The I-NO/PPHN Study Group. Pediatrics. 1998;101(3 Pt 1):325-334.

40. Thébaud B, Arnal JF, Mercier JC, Dinh-Xuan AT. Inhaled and exhaled nitric oxide. Cell Mol Life Sci. 1999;55(8-9):1103-1112.

41. Lowson SM. Alternatives to nitric oxide. Br Med Bull. 2004; 70:119-131.

42. Ortitz RM, Cilley RE, Bartlett RH. Extracorporeal membrane oxygenation in pediatric respiratory failure. Pediatr Clin North Am. 1987;34(1):39-46

43. The Neonatal Inhaled Nitric Oxide Study Group. Inhaled nitric oxide in full-term and nearly full-term infants with hypoxic respiratory failure. New Eng J Med. 1997;336:597-604.

44. Kinsella JP, Abman SH. Inhaled nitric oxide therapy in children. Paediatr Respir Rev. 2005;6(3):190-198.

45. Abman SH. Neonatal pulmonary hypertension: a physiologic approach to treatment. Pediatr Pulmonol Suppl. 2004;26:127-128.

46. Levin DL, Heymann MA, Kitterman JA, Gregory GA, Phibbs RH, Rudolph AM. Persistent pulmonary hypertension of the newborn infant. J Pediatr. 1976;89(4):626-630.

47. Hermon M, Golej J, Burda G, Marx M, Trittenwein G, Pollak A. Intravenous prostacyclin mitigates inhaled nitric oxide rebound effect: A case control study. Artif Organs. 1999;23(11):975-978.

48. Göthberg S, Edberg KE, Tang SF, Michelsen S, Winberg P, Holmgren D, et al. Residual pulmonary hypertension in children after treatment with inhaled nitric oxide: a follow-up study regarding cardiopulmonary and neurological symptoms. Acta Paediatr. 2000;89(12):1414-1419.

49. Bizzarro M, Gross I. Inhaled nitric oxide for the postoperative management of pulmonary hypertension in infants and children with congenital heart disease. Cochrane Database Syst Rev. 2009;4:CD005055.

50. Macrae DJ, Field D, Mercier JC, et al. Inhaled nitric oxide therapy in neonates and children: reaching a European consensus. Intensive Care Med. 2004;30(3):372-380.

51. Chou P, Blei ED, Shen-Schwarz S, Gonzalez-Crussi F, Reynolds M. Pulmonary changes following extracorporeal membrane oxygenation: autopsy study of 23 cases. Hum Pathol. 1993;24(4):405-412.

52. Clark RH, Huckaby JL, Kueser TJ, et al. Low-dose nitric oxide therapy for persistent pulmonary hypertension: 1 year follow-up. J Perinatol. 2003;23(4):300-303.

53. Fakioglu H, Totapally BR, Torbati D, Raszynski A, Sussmane JB, Wolfsdorf J. Hypoxic respiratory failure in term newborns: clinical indicators for inhaled nitric oxide and extracorporeal membrane oxygenation therapy. J Crit Care. 2005;20(3):288-293.
54. Lammers AE, Hislop AA, Flynn Y, Haworth SG. Epoprostenol treatment in children with severe pulmonary hypertension. Heart. 2007; (6):739-743.

55. Maiya S, Hislop AA, Flynn Y, Haworth SG. Response to bosentan in children with pulmonary hypertension. Heart. 2006;92(5):664-670.

56. Wimmer M, Salzer U, Schlemmer M, Marx M, Proll E. Experience with long-term nifedipine therapy in paediatric cardiological patients. Padiatr Padol. 1990;25(3):181-193.

57. Houde C, Bohn DJ, Freedom RM, Rabinovitch M. Profile of paediatric patients with pulmonary hypertension judged by responsiveness to vasodilators. Br Heart J. 1993;70(5):461-468.

58. Mawatari E, Hongo M, Sakai A, et al. Amlodipine prevents monocrotaline-induced pulmonary arterial hypertension and prolongs survival in rats independent of blood pressure lowering. Clin Exp Pharmacol Physiol. 2007;34(7):594-600.

59. Adatia I, Perry S, Landzberg M, Moore P, Thompson JE, Wessel DL. Inhaled nitric oxide and hemodynamic evaluation of patients with pulmonary hypertension before transplantation. J Am Coll Cardiol. 1995;25(7):1656-1664.

60. Weimann J, Ullrich R, Hromi J, et al. Sildenafil is a pulmonary vasodilator in awake lambs with acute pulmonary hypertension. Anesthesiology. 2000;92(6):1702-1712.

61. Reffelmann T, Kloner RA. Therapeutic potential of phosphodiesterase 5 inhibition for cardiovascular disease. Circulation. 2003;108(2): 239-244.

62. Leibovitch L, Matok I, Paret G. Therapeutic applications of sildenafil citrate in the management of paediatric pulmonary hypertension. Drugs. 2007;67(1):57-73.

63. Humpl T, Reyes JT, Holtby H, Stephens D, Adatia I. Beneficial effect of oral sildenafil therapy on childhood pulmonary arterial hypertension: twelve-month clinical trial of a single-drug, open-label, pilot study. Circulation. 2005;111(24):3274-3280.

64. Rossi R, Nuzzo A, Lattanzi A, Coppi F, Modena MG. Sildenafil improves endothelial function in patients with pulmonary hypertension. Pulm Pharmacol Ther. 2008;21(1):172-177.

65. Diller GP, van Eijl S, Okonko DO, et al. Circulating endothelial progenitor cells in patients with Eisenmenger syndrome and idiopathic pulmonary arterial hypertension. Circulation. 2008;117(23):3020-3030.

66. Barnett CF, Machado RF. Sildenafil in the treatment of pulmonary hypertension. Vasc Health Risk Manag. 2006;2(4):411-422.

67. Spring RM, Ulrich S, Huber LC, et al. Sildenafil for pulmonary hypertension: dose-dependent improvement in exercise performance. Pulm Pharmacol Ther. 2008;21(3):516-521.

68. Galiè N, Ghofrani HA, Torbicki A, et al. Sildenafil citrate therapy for pulmonary arterial hypertension. $N$ Engl J Med. 2005;353:2148-2157.

69. Bharani A, Mathew V, Sahu A, et al. The efficacy and tolerability of sildenafil in patients with moderate-to-severe pulmonary hypertension. Indian Heart J. 2003;55:55-59.

70. Atz AM, Lefler AK, Fairbrother DL, Uber WE, Bradley SM. Sildenafil augments the effect of inhaled nitric oxide for postoperative pulmonary hypertensive crises. J Thorac Cardiovasc Surg. 2002;124(3): 628-629.

71. Kothari SS, Duggal B. Chronic oral sildenafil therapy in severe pulmonary artery hypertension. Indian Heart J. 2002;54(4):404-409

72. Lee SH, Rubin LJ. Current treatment strategies for pulmonary arterial hypertension. J Intern Med. 2005;258(3):199-215.

73. Della Torre F, Della Torre E, Di Berardino F. Sildenafil in pulmonary hypertension. Sarcoidosis Vasc Diffuse Lung Dis. 2005;22(1):78-79.

74. Teixeira CE, Priviero FB, Webb RC. Differential effects of the phosphodiesterase type 5 inhibitors sildenafil, vardenafil, and tadalafil in rat aorta. J Pharmacol Exp Ther. 2006;316(2):654-661.

75. Toque HA, Teixeira CE, Priviero FB, Morganti RP, Antunes E, De Nucci G. Vardenafil, but not sildenafil or tadalafil, has calciumchannel blocking activity in rabbit isolated pulmonary artery and human washed platelets. Br J Pharmacol. 2008;154(4):787-796.

76. Lang IM, Bonderman D, Kneussl M, Marx M. Paediatric pulmonary vascular disease. Paediatr Respir Rev. 2004;5(3):238-248. 
77. Giaid A, Yanagisawa M, Langleben D, Michel RP, Levy R, Shennib H, et al. Expression of endothelin-1 in the lungs of patients with pulmonary hypertension. N Engl J Med. 1993;328(24):1732-1739.

78. Cacoub P, Dorent R, Nataf P, Carayon A. Endothelin-1 in pulmonary hypertension. N Engl J Med. 1993;329(26):1967-1968.

79. Rosenzweig EB, Ivy DD, Widlitz A, et al. Effects of long-term bosentan in children with pulmonary arterial hypertension. $J$ Am Coll Cardiol. 2005;46(4):697-704.

80. Galiè N, Beghetti M, Gatzoulis MA, et al. Bosentan therapy in patients with Eisenmenger syndrome: a multicenter, double-blind, randomized, placebo-controlled study. Circulation. 2006;114(1):48-54.

81. Giannakoulas G, Dimopoulos K, Gatzoulis MA. Bosentan in mild pulmonary hypertension. Lancet. 2008;372(9651):1730-1731; author reply 1731 .

82. Beghetti M, Hoeper MM, Kiely DG, Carlsen J, Schwierin B, Segal ES. Safety experience with bosentan in 146 children $2-11$ years old with pulmonary arterial hypertension: results from the European Postmarketing Surveillance program. Pediatr Res. 2008;64(2): 200-204.

83. Van Loon RLE, Hoendermis ES, Duffels MGJ, et al. Long-term effect of bosentan in adults versus children with pulmonary arterial hypertension associated with systemic-to-pulmonary shunt: does the beneficial effect persist? Am Heart J. 2007;154:776-782.

84. Apostolopoulou SC, Rammos S. Sitaxsentan in pulmonary arterial hypertension. Chest. 2003;123(5):1772; author reply 1772-1773.

85. Barst RJ, Rich S, Widlitz A, Horn EM, McLaughlin V, McFarlin J. Clinical efficacy of sitaxsentan, an endothelin-A receptor antagonist, in patients with pulmonary arterial hypertension: open-label pilot study. Chest. 2002;121(6):1860-1868.

86. Benza RL, Barst RJ, Galie N, et al. Sitaxsentan for the treatment of pulmonary arterial hypertension: a 1-year, prospective, open-label observation of outcome and survival. Chest. 2008;134(4):775-782.

87. Mehta PK, Simpson L, Lee EK, Lyle TA, McConnell ME, Book WM. Endothelin receptor antagonists improve exercise tolerance and oxygen saturations in patients with Eisenmenger syndrome and congenital heart defects. Tex Heart Inst J. 2008;35(3):256-261.

88. Galiè N, Olschewski H, Oudiz RJ, et al. Ambrisentan for the treatment of pulmonary arterial hypertension: results of the ambrisentan in pulmonary arterial hypertension, randomized, double-blind, placebo-controlled, multicenter, efficacy (ARIES) study 1 and 2. Circulation. 2008;117(23):3010-3019.

89. Tudor A, Muşat A, Bari M, Peța D, Cochior D. Observations on peripheral microcirculation in young hypertensive patients. Rom $J$ Intern Med. 2005;43(1-2):73-78.

90. Barst RJ, Maislin G, Fishman AP. Vasodilator therapy for primary pulmonary hypertension in children. Circulation. 1999;99(9): 1197-1208.

91. Rosenzweig EB, Kerstein D, Barst RJ. Long-term prostacyclin for pulmonary hypertension with associated congenital heart defects. Circulation. 1999;99(14):1858-1865.

92. Rosenzweig EB, Widlitz AC, Barst RJ. Pulmonary arterial hypertension in children. Pediatr Pulmonol. 2004;38(1):2-22.

93. Takaoka S, Faul JL, Doyle R. Current therapies for pulmonary arterial hypertension. Semin Cardiothorac Vasc Anesth. 2007; 11:137-148.

94. Barst RJ. Diagnosis and treatment of pulmonary artery hypertension. Curr Opin Pediatr. 1996;8(5):512-519.

95. Badesch DB, McLaughlin VV, Delcroix M, et al. Prostanoid therapy for pulmonary arterial hypertension. J Am Coll Cardiol. 2004;43 (12 Suppl S):56S-61S.

96. Simonneau G, Barst RJ, Galie N, et al. Continuous subcutaneous infusion of treprostinil, a prostacyclin analogue, in patients with pulmonary arterial hypertension: a double-blind, randomized, placebo-controlled trial. Am J Respir Crit Care Med. 2002;165(6):800-804.

97. Ivy DD, Claussen L, Doran A. Transition of stable pediatric patients with pulmonary arterial hypertension from intravenous epoprostenol to intravenous treprostinil. Am J Cardiol. 2007;99(5):696-698.
98. Vizza CD, Sciomer S, Morelli S, et al. Long term treatment of pulmonary arterial hypertension with beraprost, an oral prostacyclin analogue. Heart. 2001;86(6):661-665.

99. Barst RJ, McGoon M, McLaughlin V, et al. Beraprost therapy for pulmonary arterial hypertension. $J$ Am Coll Cardiol. 2003;41(12): 2119-2125.

100. Baker SE, Hockman RH. Inhaled iloprost in pulmonary arterial hypertension. Ann Pharmacother. 2005;39(7-8):1265-1274.

101. Olschewski H, Simonneau G, Galiè N, et al. Inhaled iloprost for severe pulmonary hypertension. $N$ Engl J Med. 2002;347(5):322-329.

102. Gessler T, Seeger W, Schmehl T. Inhaled prostanoids in the therapy of pulmonary hypertension. J Aerosol Med Pulm Drug Deliv. 2008;21(1):1-12.

103. Ishikura K, Yamada N, Ito M, et al. Beneficial acute effects of rho-kinase inhibitor in patients with pulmonary arterial hypertension. Circ J. 2006;70(2):174-178.

104. Alapati VR, McKenzie C, Blair A, Kenny D, MacDonald A, Shaw AM. Mechanisms of U46619- and 5-HT-induced contraction of bovine pulmonary arteries: role of chloride ions. Br J Pharmacol. 2007;151(8): 1224-1234.

105. Somlyo AP, Somlyo AV. Signal transduction by G-proteins, rho-kinase and protein phosphatase to smooth muscle and non-muscle myosin II. J Physiol. 2000;522 Pt 2:177-185.

106. Shimokawa H, Takeshita A. Rho-kinase is an important therapeutic target in cardiovascular medicine. Arterioscler Thromb Vasc Biol. 2005;25(9):1767-1775.

107. Abe K, Shimokawa H, Morikawa K, et al. Long-term treatment with a Rho-kinase inhibitor improves monocrotaline-induced fatal pulmonary hypertension in rats. Circ Res. 2004;94(3):385-393

108. Fukumoto Y, Tawara S, Shimokawa H. Recent progress in the treatment of pulmonary arterial hypertension: expectation for rho-kinase inhibitors. Tohoku J Exp Med. 2007;211(4):309-320.

109. Fukumoto Y, Matoba T, Ito A, et al. Acute vasodilator effects of a Rho-kinase inhibitor, fasudil, in patients with severe pulmonary hypertension. Heart. 2005;91(3):391-392.

110. Janosi T, Peták F, Fontao F, Morel DR, Beghetti M, Habre W. Differential roles of endothelin-1 ETA and ETB receptors and vasoactive intestinal polypeptide in regulation of the airways and the pulmonary vasculature in isolated rat lung. Exp Physiol. 2008;93(11):1210-1219.

111. Tofovic SP, Zhang X, Zhu H, Jackson EK, Rafikova O, Petrusevska G. 2-Ethoxyestradiol is antimitogenic and attenuates monocrotalineinduced pulmonary hypertension and vascular remodeling. Vascul Pharmacol. 2008;48(4-6):174-183.

112. Gurbanov E, Shiliang X. The key role of apoptosis in the pathogenesis and treatment of pulmonary hypertension. Eur J Cardiothorac Surg. 2006;30(3):499-507.

113. Michelakis ED, Wilkins MR, Rabinovitch M. Emerging concepts and translational priorities in pulmonary arterial hypertension. Circulation. 2008;118:1486-1495.

114. Altieri DC. Survivin and apoptosis control. Adv Cancer Res. 2003; 88:31-52.

115. Guerard P, Rakotoniaina Z, Goirand F, et al. The HMG-CoA reductase inhibitor, pravastatin, prevents the development of monocrotalineinduced pulmonary hypertension in the rat through reduction of endothelial cell apoptosis and overexpression of eNOS. Naunyn Schmiedebergs Arch Pharmacol. 2006;373(6):401-414.

116. Rakotoniaina Z, Guerard P, Lirussi F, Rochette L, Dumas M, Goirand F, Bardou M. Celecoxib but not the combination of celecoxib + atorvastatin prevents the development of monocrotalineinduced pulmonary hypertension in the rat. Naunyn Schmiedebergs Arch Pharmacol. 2008;378(3):241-251.

117. McMurtry MS, Bonnet S, Michelakis ED, Bonnet S, Haromy A, Archer SL. Statin therapy, alone or with rapamycin, does not reverse monocrotaline pulmonary arterial hypertension: the rapamcyinatorvastatin-simvastatin study. Am J Physiol Lung Cell Mol Physiol. 2007;293(4):L933-L940. 
118. Hervé P, Launay JM, Scrobohaci ML, et al. Increased plasma serotonin in primary pulmonary hypertension. Am J Med. 1995;99(3): 249-254.

119. MacLean MR, Deuchar GA, Hicks MN, et al. Overexpression of the 5-hydroxytryptamine transporter gene: effect on pulmonary hemodynamics and hypoxia-induced pulmonary hypertension. Circulation. 2004;109(17):2150-2155.

120. Marcos E, Adnot S, Pham MH, et al. Serotonin transporter inhibitors protect against hypoxic pulmonary hypertension. Am J Respir Crit Care Med. 2003;168(4):487-493.

121. Guignabert C, Raffestin B, Benferhat R, et al. Serotonin transporter inhibition prevents and reverses monocrotaline-induced pulmonary hypertension in rats. Circulation. 2005;111(21):2812-2819.

122. Kawut SM, Horn EM, Berekashvili KK, Lederer DJ, Widlitz C, Rosenzweig EB. Selective serotonin reuptake inhibitor use and outcomes in pulmonary arterial hypertension. Pulm Pharmacol Ther. 2006;19(5):370-374

123. Arima M, Kanoh T, Takagi A, Tanimoto K, Oigawa T, Matsuda S. Clinical features of acute pulmonary thromboembolism in younger patients. Circ J. 2003;67(4):330-333.

124. Castillo L, Beaumier L, Ajami AM, Young VR. Whole body nitric oxide synthesis in healthy men determined from [15N] arginine-to-[15N] citrulline labeling. Proc Natl Acad Sci U S A. 1996;93:11460-11465.

125. McMullan DM, Bekker JM, Parry AJ, et al. Alterations in endogenous nitric oxide production after cardiopulmonary bypass in lambs with normal and increased pulmonary blood flow. Circulation. 2000;102(supp1):III172-III178.

126. Barr FE, Beverley H, VanHook K, et al. Effect of cardiopulmonary bypass on urea cycle intermediates and nitric oxide levels after congenital heart surgery. J Pediatr. 2003;142:26-30.

127. Gorenflo M, Ullmann MV, Eitel K, et al. Plasma L-arginine and metabolites of nitric oxide synthase in patients with left-to-right shunt after intracardiac repair. Chest. 2005;127(4):1184-1189.

128. Tanaka E, Harigai M, Tanaka M, Kawaguchi Y, Hara M, Kamatani N. Pulmonary hypertension in systemic lupus erythematosus: evaluation of clinical characteristics and response to immunosuppressive treatment. J Rheumatol. 2002;29(2):282-287.

129. Hoeper MM. Drug treatment of pulmonary arterial hypertension: current and future agents. Drugs. 2005;65(10):1337-1354.

130. Fasnacht MS, Tolsa JF, Beghetti M; Swiss Society for Pulmonary Arterial Hypertension. The Swiss registry for pulmonary arterial hypertension: the paediatric experience. Swiss Med Wkly. 2007; 137(35-36):510-513.

131. Mogollón MV, Lage E, Cabezón S, et al. Combination therapy with sildenafil and bosentan reverts severe pulmonary hypertension and allows heart transplantation: case report. Transplant Proc. 2006;38(8):2522-2523.

132. Liu C, Chen J. Endothelin receptor antagonists for pulmonary arterial hypertension. Cochrane Database Syst Rev. 2006;3:CD004434.

133. Driscoll JA, Chakinala MM. Medical therapy for pulmonary arterial hypertension. Expert Opin Pharmacother. 2008;9(1):65-81.

134. Humbert M, Sitbon O, Simonneau G. Treatment of pulmonary arterial hypertension. N Engl J Med. 2004;351(14):1425-1436.

135. McLaughlin VV, Oudiz RJ, Frost A, et al. Randomized study of adding inhaled iloprost to existing bosentan in pulmonary arterial hypertension. Am J Respir Crit Care Med. 2006;174(11):1257-1263.

136. Haraldsson A, Kieler-Jensen N, Ricksten SE. Inhaled prostacyclin for treatment of pulmonary hypertension after cardiac surgery or heart transplantation: a pharmacodynamic study. J Cardiothorac Vasc Anesth. 1996;10(7):864-868.

137. Burgess G, Hoogkamer H, Collings L, Dingemanse J. Mutual pharmacokinetic interactions between steady-state bosentan and sildenafil. Eur J Clin Pharmacol. 2008;64(1):43-50.

138. Simonneau G, Rubin LJ, Galiè N, et al. Addition of sildenafil to long-term intravenous epoprostenol therapy in patients with pulmonary arterial hypertension: a randomized trial. Ann Intern Med. 2008;149(8):521-530.
139. Kerstein D, Levy PS, Hsu DT, Hordof AJ, Gersony WM, Barst RJ. Blade balloon atrial septostomy in patients with severe primary pulmonary hypertension. Circulation. 1995;91(7):2028-2035.

140. Rich S, Lam W. Atrial septostomy as palliative therapy for refractory primary pulmonary hypertension. Am J Cardiol. 1983;51(9):1560-1561.

141. Law MA, Grifka RG, Mullins CE, Nihill MR. Atrial septostomy improves survival in select patients with pulmonary hypertension. Am Heart J. 2007;153(5):779-784.

142. Hausknecht MJ, Sims RE, Nihill MR, Cashion WR. Successful palliation of primary pulmonary hypertension by atrial septostomy. Am J Cardiol. 1990;65(15):1045-1046.

143. Sandoval J, Gaspar J, Pulido T, Bautista E, Martínez-Guerra ML, Zeballos M. Graded balloon dilation atrial septostomy in severe primary pulmonary hypertension. A therapeutic alternative for patients nonresponsive to vasodilator treatment. J Am Coll Cardiol. 1998; (2):297-304.

144. Cheever KH. An overview of pulmonary arterial hypertension: risks, pathogenesis, clinical manifestations, and management. J Cardiovasc Nurs. 2005;20(2):108-116; quiz 117-118.

145. Huddleston CB, Bloch JB, Sweet SC, de la Morena M, Patterson GA, Mendeloff EN. Lung transplantation in children. Ann Surg. 2002; 236(3):270-276.

146. Aurora P, Edwards LB, Christie J, et al. Registry of the International Society for Heart and Lung Transplantation: eleventh official pediatric lung and heart/lung transplantation report - 2008. J Heart Lung Transplant. 2008;27(9):978-983.

147. Haworth SG. Role of the endothelium in pulmonary arterial hypertension. Vascul Pharmacol. 2006;45(5):317-325.

148. Galie' N, Rubin LJ, Hoeper M, et al. Treatment of patients with mildly symptomatic pulmonary arterial hypertension with bosentan (EARLY study): a double-blind, randomized controlled trial. Lancet. 2008;371:2093-2100.

149. Galie N, Manes A, Negro L, et al. A meta-analysis of randomized controlled trials in pulmonary arterial hypertension. Eur Heart J. 2009;30:394-403.

150. Rubin LJ, Mendoza J, Hood M, et al. Treatment of primary pulmonary hypertension with continuous intravenous prostacyclin (epoprostenol) Results of a randomized trial. Ann Intern Med. 1990;112:485-491.

151. Barst RJ, Rubin LJ, Long WA, et al. A comparison of continuous intravenous epoprostenol (prostacyclin) with conventional therapy for primary pulmonary hypertension. The Primary Pulmonary Hypertension Study Group. N Engl J Med. 1996;334:296-302.

152. Badesch DB, Tapson VF, McGoon MD, et al. Continuous intravenous epoprostenol for pulmonary hypertension due to the scleroderma spectrum of disease. A randomized, controlled trial. Ann Intern Med. 2000;132:425-434.

153. Channick RN, Simonneau G, Sitbon O, et al. Effects of the dual endothelin receptor antagonist bosentan in patients with pulmonary hypertension: a randomised placebo-controlled study. Lancet. 2001; 358:1119-1123.

154. Langleben D, Christman BW, Barst RJ, et al. Effects of the thromboxane synthetase inhibitor and receptor antagonist terbogrel in patients with primary pulmonary hypertension. Am Heart J. 2002;143:E4

155. Galie N, Humbert M, Vachiery JL, et al. Effects of beraprost sodium, an oral prostacyclin analogue, in patients with pulmonary arterial hypertension: a randomised, double-blind placebo-controlled trial. J Am Coll Cardiol. 2002;39:1496-1502.

156. Rubin LJ, Badesch DB, Barst RJ, et al. Bosentan therapy for pulmonary arterial hypertension. N Engl J Med. 2002;346:896-903.

157. Sastry BKS, Narasimhan C, Reddy NK, Raju BS. Clinical efficacy of sildenafil in primary pulmonary hypertension. 1: A randomized, placebo-controlled, doubleblind, crossover study. J Am Coll Cardiol. 2004;43:1149-1153.

158. Humbert M, Barst RJ, Robbins IM, et al. Combination of bosentan with epoprostenol in pulmonary arterial hypertension: BREATHE-2. Eur Respir J. 2004;24:353-359. 
159. Barst RJ, Langleben D, Frost A, et al. Sitaxsentan therapy for pulmonary arterial hypertension. Am J Respir Crit Care Med. 2004;169(4):441-447.

160. Galie N, Ghofrani HA, Torbicki A, et al. The Sildenafil Use in Pulmonary Arterial Hypertension (SUPER) Study Group. Sildenafil citrate therapy for pulmonary arterial hypertension. $N$ Engl J Med. 2005;353:2148-2157.

161. Wilkins MR, Paul GA, Strange JW, et al. Sildenafil versus Endothelin Receptor Antagonist for Pulmonary Hypertension (SERAPH) study. Am J Respir Crit Care Med. 2005;171:1292-1297.

162. Singh T, Rohit M, Grover A, Malhotra S, Vijayvergiya R. A randomized, placebo controlled, double-blind, crossover study to evaluate the efficacy of oral sildenafil therapy in severe pulmonary artery hypertension. Am Heart J. 2006;151:851.e1-851.e5.
163. Barst RJ, Langleben D, Badesch D, et al. Treatment of pulmonary arterial hypertension with the selective endothelin-A receptor antagonist sitaxsentan. J Am Coll Cardiol. 2006;47(10):2049-2056.

164. McLaughlin VV, Oudiz RJ, Frost A, et al. Randomized study of adding inhaled iloprost to existing bosentan in pulmonary arterial hypertension. Am J Respir Crit Care Med. 2006;174:1257-1263.

165. Hoeper M, Leuchte H, Halank M, Wilkens H, Meyer FJ, Seifarth HJ, et al. Combining inhaled iloprost with bosentan in patients with idiopathic pulmonary arterial hypertension. Eur Resp J. 2006;4:691-694.

166. Hislop A. Developmental biology of the pulmonary circulation. Paediatr Respir Rev. 2005;6(1):35-43.

167. Torres F. Systematic review of randomised, double-blind clinical trials of oral agents conducted in patients with pulmonary arterial hypertension. Int J Clin Pract. 2007;61(10):1756-1765.

\section{Publish your work in this journal}

Vascular Health and Risk Management is an international, peerreviewed journal of therapeutics and risk management, focusing on concise rapid reporting of clinical studies on the processes involved in the maintenance of vascular health; the monitoring, prevention and treatment of vascular disease and its sequelae; and the involvement of metabolic disorders, particularly diabetes. This journal is indexed on PubMed Central and MedLine. The manuscript management system is completely online and includes a very quick and fair peer-review system, which is all easy to use. Visit http://www.dovepress.com/ testimonials.php to read real quotes from published authors. 